Informatika i sistemy upravleniya. - 2017. - No. 1(51). - P. 100-106.

Gladkikh V.A. (gladkikh @as.khb.ru), Krivosheev I.A.

Computer center of the FEB RAS

\title{
STEP-INDEX PROFILE WAVE-GUIDE AND GRADIENT PROFILE (CUT PARABOLIC) WAVE-GUIDE:WAVE FIELD COMPARISON
}

Here we present final analytical expressions for a single-mode operation of a waveguide field within the model of a cut parabolic profile of the refraction index. These expressions are presented in regard to field change inside the waveguide field during the profile transition of the refraction index from the step-index to the gradient one. The data were obtained during the first iteration and show a significant change in the dominant mode energy.

Keywords: electromagnetic field, differential equations, Green function, Bessel function, optical waveguide, refractive index profile.

DOI: 10.22250/isu.2017.51.100-106

For citation:

Gladkikh V.A., Krivosheev I.A. STEP-INDEX PROFILE WAVE-GUIDE AND GRADIENT PROFILE (CUT PARABOLIC) WAVE-GUIDE:WAVE FIELD COMPARISON // Informatika i sistemy upravleniya. - 2017. - No. 1(51). - P.100-106. 